Volume 2 Issue 1, March 2018: pp. 371-386. Copyright (c) 2018 HOLREV. Faculty of Law, Halu Oleo University, Kendari, Southeast Sulawesi, Indonesia. ISSN: 2548-1762 I e-ISSN: 2548-1754. Open Access at: http://ojs.uho.ac.id/index.php/holrev/

Halu Oleo Law Review is licensed under a Creative Commons Attribution 4.0 International License, which permits unrestricted use, distribution, and reproduction in any medium, provided the original work is properly cited.

\title{
Pemahaman Terhadap Pemberlakuan Hukum Islam di Indonesia
}

\author{
The Understanding of Applied Islamic Law in Indonesia
}

\author{
Prawitra Thalib \\ Fakultas Hukum Universitas Airlangga \\ E-mail: prawitra@fh.unair.ac.id
}

\begin{abstract}
Islamic law in Indonesia has become inner-social-life, it growth and developed before Indonesia stood and growth on social life. Although Indonesia was not Islamic State but does not mean it has an obstacle to implement the Indonesian Islamic Law. This is because that the value in that law has come to be a strong artery in every Indoensiaa single life. Besides, it is often interpreted into the norms by contemporer experts. Islamic Law in Indonesia applied the benefit parameter that concerned whether its neccesery a certain rule or not. In addition, its primary role is to assure that every its single norm was not paradoxically went againt Qoran and Sunnah. By applying Islamic Law into either forming or interpreting in the law, so that can be assured the law has complied the standard which to be put on Indonesian life. Thus, this norm was not doubt which is appearing a new problem and not create a conflict norm in application.
\end{abstract}

Keyword: Benefit, Islamic Law, and Norm

Abstrak: Hukum Islam di Indonesia telah menjadi jati diri rakyat di Indonesia, hukum Islam telah tumbuh dan berkembang sebelum Negara tersebut berdiri dan telah mengakar dalam segala aspek kehidupan masyarakatnya. Sekalipun Indonesia bukan Negara Islam hal tersebut bukanlah menjadi penghalang pemberlakuan hukum Islam di Indonesia. Hal ini dikarenakan nilai-nilai yang terkandung dalam hukum Islam tersebut merupakan nadi dalam setiap aspek kehidupan masyarakat Indonesia. Selain itu, nilai tersebut tidak jarang nilai-nilai tersebut diinterpretasikan ke dalam norma oleh para ahli hukum kontemporer. Hukum Islam di Indonesia menggunakan suatu parameter kemaslahatan mengenai perlu atau tidaknya suatu hukum dalam suatu persoalan tertentu. Sebagai tambahan, peran utamanya adalah untuk memastikan bahwa setiap hukum Islam yang dinormakan tersebut tidak bertentangan dengan nash yaitu Al-Quran dan Sunnah. Dengan mengaplikasikan hukum Islam ke dalam setiap upaya pembuatan atau pun penafsiran suatu hukum, maka dapat dipastikan hukum tersebut telah memenuhi standar untuk di aplikasikan ke dalam masyarakat Indonesia. Dengan demikian hal ini tidak dikhawatirkan hukum tersebut akan menimbulkan persoalan baru atau menimbulkan konflik norma dalam pengaplikasiannya. 


\section{PENDAHULUAN}

Pembahasan tentang hukum Islam dan qowaid fiqhiyyah (kaidah-kaidah fiqh) adalah dua hal yang paling utama, terutama dalam melakukan pemahaman terhadap hukum Islam, hal ini dikarenakan penguasaan terhadap kaidah fiqh akan menjadi benang merah terhadap penyelesaian atau dari masalah-masalah yang timbul yang disesuaikan dengan tempat, waktu dan kebiasaan yang berlainan, sehingga sesungguhnya qowaid fiqhiyyah tersebut akan menjadikan hukum Islam selalu fleksibel dalam menanggapi isu-isu sosial, ekonomi, politik, budaya dan hukum.

Membahas tentang pemahaman hukum Islam sesungguhnya tidak terlepas dari istilah qowaid fiqiyyah, yang secara etimologi kata qowaid berasal dari bahasa Arab alAqidah yang berarti fondasi yang kemudian melahirkan kata qaidah yang berarti dasar, sedangkan qowaid adalah jamak dari qaidah sehingga mempunyai makna dasar-dasar. ${ }^{1}$ Sementara itu secara terminologi istilah fiqhiyyah berasal dari bahasa Arab fiqh yang bersumber dari Q.S. At-Taubah ayat 122, "liyatafaqqahu fiddin" yang berarti untuk memperdalam pengatahuan mereka tentang agama, tafaqqahu inilah yang kemudian melahirkan konsep fiqh sebagai suatu al-fahmu atau pemahaman. Sehingga fiqh dapat dikatakan sebagai suatu pemahaman tentang syariah atau ilmu yang memahami syariah sebagai aturan-aturan yang ditetapkan Allah SWT bagi umatnya. ${ }^{2}$

Berdasarkan pengertian tersebut maka dapat disimpulkan bahwa qowaid fiqhiyyah mempunyai arti sebagai kaidah-kaidah umum dalam memahami syariah sebagai suatu aturan-aturan yang ditetapkan Allah SWT bagi umatnya, dengan kata lain qowaid fiqhiyyah dapat berupa pedoman yang memudahkan para ahli hukum Islam untuk menyimpulkan hukum terhadap suatu persoalan hukum, hal ini tentu saja menjadikan qowaid fiqhiyyah ini sebagai garis besar dalam melakukan suatu ijtihad terhadap suatu masalah hukum, karena fiqh tidak mungkin dapat berdiri tanpa ada fondasi dasar yang menjadikan fiqh tersebut berdiri teguh, sehingga dapat menyelesaikan masalah. Dalam hal ini perlu

1 Ahmad Warson, Kamus Al-Munawwir Arab-Indonesia, Pustaka Progressif, 1997, hlm. 1138.

2 Prawitra Thalib, Syariah: Konsep dan Hermeneutika, Cetakan Pertama, Surabaya: Lutfansyah Mediatama, 2013, hlm. 22. 
dipahami pula bahwa fiqh sifatnya khusus, sementara itu qowaid fiqhiyyah mempunyai sifat yang sangat umum sekali.

Ilmu yang memperbincangkan hukum Islam adalah fiqh, oleh karenanya apabila hukum Islam tidak terlepas dari qowaid fiqiyyah maka qowaid fiqiyyah tidak akan terlepas dari fiqh karena fiqh adalah produk hukum Islam. Gambaran dari kekhususan fiqh dan keumuman qowaid fiqhiyyah dapat di jelaskan sebagai berikut, bahwa fiqh merupakan pemahaman secara umum terhadap prinsip-prinsip Islam dan hukum-hukum yang terkandung di dalamnya, pemahaman terhadap isu-isu hukum tersebut terbagi secara spesifik sesuai dengan kajian dari masing-masing isu hukum tertentu, misalkan hukum perkawinan diatur dalam fiqh munakahat, hukum waris diatur dalam fiqh faraidh, hukum perdata diatur dalam fiqh muamalah, dan masih banyak bidang-bidang hukum lain yang diatur dalam fiqh yang berbeda pula. Setiap cabang dari fiqh mempunyai pembahasan tersendiri yang berbeda satu dengan yang lain, sebagai contoh fiqh muamalah mengatur masalah keperdataan saja sementara itu fiqh faraidh mengatur masalah kewarisan, kedua fiqh tersebut berdiri sendiri-sendiri tanpa mencampuri satu sama lain, karena bidang pemahaman dan pembahasan isu hukumnya berbeda, inilah yang dikatakan fiqh mempunyai sifat yang khusus. ${ }^{3}$

Sementara itu qowaid fiqhiyyah dikatakan mempunyai sifat yang umum, hal ini dikarenakan setiap fiqh yang ada baik itu fiqh muamalah, fiqh faraidh atau fiqh munakahat, masing-masing berdiri atas fondasi yang sama atau masing-masing berdiri atas kaidahkaidah yang sama yang lebih dikenal dengan istilah qowaid fiqhiyyah, nilai-nilai yang terkandung dalam qowaid fiqhiyyah harus menjadi nilai dasar dari setiap fiqh yang ada. Oleh karena itu sekalipun pemahaman dan pembahasan dari setiap fiqh berbeda namun masing-masing fiqh berdiri di atas kaidah-kaidah yang sama, inilah yang dinamakan dengan keumuman dari qowaid fiqhiyyah. Adapun penghubung antara qowaid fiqhiyyah dan fiqh adalah ushul fiqh, dalam hal ini dapat dijelaskan apabila qowaid fiqhiyyah adalah fondasi untuk membuat suatu fiqh, maka upaya untuk membuat fiqh tersebut harus menggunakan metode atau cara yang dinamakan dengan ushul fiqh, antara qowaid fiqhiyyah, ushul fiqh dan fiqh masing-masing mempunyai urutan dan keterkaitan yang jelas antara satu dengan yang lain, kesemuanya merupakan suatu upaya pemahaman terhadap

3 Ibid, hlm. 23. 
hukum Islam supaya dapat diaplikasikan ke dalam segala aspek kehidupan yang tidak terkekang oleh waktu dan zaman.

Hukum Islam dan qowaid fiqhiyyah mempunyai keterkaitan antara satu dengan yang lain, hal ini dikarenakan kedinamisan hukum Islam yang di wujudkan dalam fiqh amat bergantung pada qowaid fiqhiyyah, dalam hal ini karakteristik keumuman atau generalitas dari kaidah-kaidah tersebutlah yang menjadikan hukum Islam dapat diterapkan pada segala kondisi di setiap waktu dan zaman. qowaid fiqhiyyah menjadikan fiqh sebagai ilmu yang bersifat khusus, relatif dan sangat dipengaruhi oleh kondisi tempat dan waktu (qabil lin iqash, qabil lit taghyir), betapa tidak perkembangan masyarakat, budaya, ilmu pengetahuan dan teknologi kesemua hal tersebut secara tidak langsung juga mempengaruhi perkembangan hukum Islam, syariah tidak dapat berubah karna sifatnya yang abadi, karena mengubah syariah sama saja dengan mengubah ketentuan yang ada dalam Al-Quran dan Sunnah, namun penginterpretasian syariah tersebut yang dapat berubah yang disesuaikan dengan perkembangan zaman, yang mana hal itu dijembatani oleh qowaid fiqhiyyah, sebagai parameter dalam upaya memahami makna yang terkandung dalam Al-Quran dan Sunnah yang dituangkan dalam fiqh, sebagai bentuk pengaplikasian hukum Islam kontemporer.

\section{ANALISIS DAN PEMBAHASAN}

Islam bersumber pada dua sumber utama yaitu Al-Quran dan Sunnah, yang kerap kali dikatakan sebagai dalil-dalil pokok hukum Islam, di samping itu selain Al-Quran dan Sunnah ada juga beberapa dalil pendukung dalam hukum Islam yaitu ijma', qiyas, istihsan, masalahah mursalah, urf dan syarún man qoblana, yang kesemuanya adalah alat bantu untuk memahami makna hakiki yang terkandung dalam Al-Quran dan Sunnah. Berbicara tentang hukum Islam ada dua bentuk utama yaitu syariah dan fiqh. Syariah adalah hukum Islam dalam makna yang luas yang mencakup aspek akidah, akhlak dan amaliah, yang mencakup norma dalam agama Islam, oleh sebab itu syariah cakupannya lebih luas. Sementara itu fiqh adalah hukum Islam praktis yang bersumber dari dalil-dalil tafshily atau terperinci yang khusus mengatur suatu bidang hukum saja, ${ }^{4}$ dengan kata lain dapat dipahami pula bahwa syariah adalah peraturan yang diturunkan Allah SWT kepada manusia supaya hendaknya senantiasa di pedomani ketika berhubungan dengan Tuhan,

4 Syarif Hidayatullah, Qawaid Fiqiyyah dan Penerapannya Dalam Transaksi Keuangan Syariah Kontemporer (muámalat, maliyyah islamiyah, muásirah), Gramata Publishing, 2012, hlm. 3. 
manusia dan lingkungannya, sedangkan ilmu yang memperbincangkan syariah itulah yang dinamakan dengan fiqh. ${ }^{5}$ Sehingga fiqh dapat dikatakan sebagai syariah atau hukum Islam dalam arti sempit. Adapun mengenai perbedaan antara syariah dan fiqh dapat diuraikan sebagai berikut: 6

1. Syariah mempunyai cakupan yang luas yang meliputi seluruh tindakan dan perbuatan manusia, sementara fiqh hanya mengacu kepada apa yang secara umum dimengerti sebagai tindakan manusia yang didasarkan pada sesuatu yang legal dan ilegal.

2. Syariah merupakan suatu wadah yang terdiri dari berbagai ketentuan yang terdapat di dalam Al-Quran dan Sunnah yang meliputi tiga komponen utama yaitu akidah, akhlak dan fiqh, sementara itu fiqh hanyalah merupakan salah satu komponen dari syariah.

3. Syariah mempunyai karakteristik yang sempurna dan tidak dapat diubah-ubah, sementara itu fiqh mempunyai karakteristik yang selalu berubah mengikuti perubahan waktu, ruang dan tempat dimana fiqh tersebut diterapkan.

4. Syariah didasarkan dari wahyu-wahyu yang hanya diperoleh dari Al-Quran dan Sunnah, sedangkan fiqh adalah hasil penalaran dan deduksi para ahli hukum yang didasarkan pada perkembangan pengetahuan yang terus berubah seiring perubahan zaman.

5. Syariah mempunyai beberapa tingkatan perbuatan yang dimulai dari sesuatu yang diizinkan hingga sesuatu yang tidak diizinkan, sementara itu fiqh hanya mengatur tentang tindakan yang legal dan ilegal saja.

Kemudian Yusuf Musa dalam bukunya yang berjudul al Madkhal li Dirasah al Fiqh al Islamy juga mengemukakan tiga perbedaan syariah dan fiqh yang antara lain adalah : ${ }^{7}$

1. Dalam beberapa hal, syariah mempunyai cakupan yang lebih luas dari fiqh, hal ini dikarenakan syariah meliputi seluruh ajaran agama yakni akidah, ibadah dan hukum, sementara itu Fiqh hanya meliputi perbuatan saja;

2. Ditinjau dari subjeknya, maka subjek syariah adalah Allah SWT atau al Syari' sedangkan fiqh subjeknya adalah manusia atau al Faqih, oleh karena itu syariah

5 Abd. Shomad, Hukum Islam: Penormaan Prinsip Syariah Dalam Hukum Indonesia, Cetakan Pertama, Jakarta: Kencana Prenada Media Group, 2010.

6 Prawitra Thalib, Op.Cit., hlm. 22-23.

7 Renny Supriyatni, Pengantar Hukum Islam Dasar-Dasar dan Aktualisasinya Dalam Hukum Positif, Bandung: Widya Padjadjaran, Maret 2011, hlm. 12-14. 
sebagai ciptaan Allah SWT bersifat sempurna dan abadi kebenarannya, sedangkan fiqh dapat berubah sesuai dengan pemahaman para Faqih yang disebabkan oleh faktor sosial budaya dan historisnya;

3. Dari penggunaan istilah juga dapat ditemukan perbedaannya, dalam hal ini penggunaan istilah syariah telah digunakan sejak awal sejarah perkembangan Islam sendiri, sedangkan penggunaan istilah fiqh baru digunakan setelah lahirnya cabang-cabang ilmu keagamaan dalam Islam pada abad kedua Hijriyah.

Fenomena pemikiran hukum Islam kontemporer sesungguhnya merupakan respons atas kondisi sosial pasca runtuhnya Kesultanan Turki Usmani, munculnya gerakan-gerakan pembaharuan Islam seperti Tanzimat dan Salafiyah, telah membawa warna tersendiri bagi perkembangan hukum Islam kontemporer, ditambah lagi dengan adanya pengaruh sekularisme dan kolonialisme, kesemuanya baik secara langsung maupun tidak langsung telah memberikan pengaruh bagi perkembangan hukum Islam, ditambah lagi kekalahan negara-negara Arab dari Israel pada perang enam hari Juni 1967, yang berujung pada penanda tanganan perjanjian Camp David, menyebabkan dunia Islam secara global terasa telah kehilangan pengayom, hal ini menyebabkan umat Islam secara sistematis telah tercerai berai, masing-masing hidup dengan jalan masing-masing, fakta ini yang kemudian melahirkan fakta perlunya pembaharuan hukum Islam, sehingga dapat mematahkan pandangan skeptis bahwa hukum Islam sudah ketinggalan zaman.

Menurut Ashiddiqy hukum Islam dikategorikan mempunyai tiga karakter yang abadi, kekal dan tidak berubah, yakni : pertama, takamul yaitu sempurna, bulat dan tuntas. Hal ini dipahami bahwa hukum Islam membentuk umat dalam suatu ketentuan yang bulat, walaupun mereka berbeda-beda bangsa dan berlainan suku, tetapi mereka satu kesatuan yang tidak dapat dipisahkan. Kedua, wasathiyat (harmonis), yakni hukum Islam menempuh jalan tengah, jalan yang seimbang dan tidak berat sebelah, tidak berat ke kanan dengan mementingkan kejiwaan dan tidak berat ke kiri dengan mementingkan perbedaan. Hukum Islam selalu menyelaraskan di antara kenyataan dan fakta dengan ideal dari citacita. Ketiga, Harakah (dinamis), yakni hukum Islam mempunyai kemampuan bergerak dan berkembang, mempunyai daya hidup dan dapat membentuk diri sesuai dengan perkembangan dan kemajuan zaman. Hukum Islam terpencar dari sumber yang luas dan 
dalam, yang memberikan kepada manusia sejumlah hukum yang positif dan dapat dipergunakan pada setiap tempat dan waktu. ${ }^{8}$

Adapun yang menjadi problem utama pemahaman hukum Islam untuk diterapkan di Indonesia pada dasarnya berhubungan dengan sikap terhadap tradisi (turats) di satu sisi dan sikap terhadap modernisasi (hadatsah) di sisi yang lain. Apabila pemikiran tradisional menyikapi modernisasi dengan apriori demi konservasi, maka lain halnya dengan pemikiran modern yang menyikapi tradisi sebagai sesuatu yang mesti dilenyapkan demi terwujudnya kemajuan, karena tradisi dianggap sebagai cadas yang menghalangi proses kemajuan itu sendiri, dalam hal ini konsep hukum Islam Kontemporer terjebak dalam pertikaian kritis tentang tradisi dan modernisasi yang keduanya berhadapan sebagai bentuk tantangan kontemporer.

Sekularisasi pada masa modern secara perlahan telah mempengaruhi budaya kontemporer pada masa sekarang ini. Sejak abad ke 18, ketika ilmu pengetahuan dan teknologi mulai berkembang di golongan masyarakat telah menjadikan manusia beraktivitas menjadi lebih efektif dan efisien. Perkembangan teknologi yang diawali ditemukannya mesin uap oleh James Watttelah memberikan pengaruh yang sangat signifikan terutama dalam hal teknologi. Ketika di zaman modern muncul hal-hal pribadi yang memisahkan diri dari ruang publik. Maka secara otomatis telah mengembangkan pemikiran sekularisasi yang memisahkan urusan pribadi dengan urusan publik. Berbicara tentang sekularisasi pada awalnya di pelopori oleh pemisahan antara kekuasaan Gereja dan Negara, yang secara otomatis kehidupan beragama bagi rakyat tidak lagi diatur oleh Negara. Memang betul sekularisasi secara parsial telah memberikan pengaruh terhadap perkembangan hukum Islam kontemporer, namun hal ini harus di jaga jangan sampai hukum Islam kehilangan ruh sejatinya sebagai wahyu Illahiah yang bersumber dari Allah SWT. Kemurnian hukum Islam yang bersumber dari agama Islam haru tetap terjaga, norma yang terkandung dalam Al-Quran dan Sunnah harus diaplikasikan ke dalam segala aspek kehidupan umat muslim, di setiap tempat waktu dan zaman, upaya pemaknaan kontemporer dari nilai-nilai yang terkandung dalam nash (Al-Quran dan Sunnah), inilah yang berupaya dijembatani oleh qowaid fiqhiyyah sehingga hukum Islam tetap hidup dalam dimensi kontemporer tanpa mengurangi makna dan hakikatnya sebagai wahyu.

8 Hasbi Ash-Shiddiqy, Filsafat Hukum Islam, Semarang: Pustaka Rizki Putra, 2001, hlm. 105-108. 
Qowaid fiqhiyyah adalah kaidah-kaidah universal yang di dalamnya terkandung bagian-bagian persoalan yang sama, yang dapat dikelompokkan dalam satu garis besar yang sama yang kemudian melahirkan berbagai macam cabang-cabang fiqh. qowaid fiqhiyyah telah disepakati oleh para jumhur ulama sebagai suatu landasan yang tidak kalah pentingnya dengan dalil-dalil pokok maupun penunjang yang ada dalam hukum Islam, hal ini dikarenakan qowaid fiqhiyyah dapat memudahkan seorang mujtahid untuk melakukan pemahaman terhadap hukum Islam. Sehingga seseorang tidak pantas untuk dikatakan sebagai mujtahid apabila tidak menguasai qowaid fiqhiyyah. Singkat kata untuk melakukan ijtihad pemahaman terhadap kaidah-kaidah fiqh amatlah diperlukan. Peranan ijtihad sangat besar dalam pembaruan hukum Islam. Pembaruan tidak mungkin dilaksanakan tanpa adanya mujtahid yang memenuhi syarat untuk melaksanakannya. Berbicara tentang pembaharuan hukum Islam dan ijtihad dalam hukum Islam, ibarat dua sisi mata uang yang tidak dapat dipisahkan antara satu dengan yang lain, saling mengisi dan melengkapi. Jika proses ijtihad dapat dilaksanakan dalam proses pembaruan Islam secara benar, maka hukum-hukum yang dihasilkan dari proses ijtihad itu akan menjawab segala persoalan yang muncul akibat tuntutan zaman.

Ruang lingkup ilmu fiqh amatlah luas, hal ini dikarenakan ilmu fiqh mencakup berbagai cabang (furu'), yang menyebabkan perlunya adanya fondasi utama yang berfungsi sebagai akar yang menopang cabang-cabang tersebut, semakin kokoh akarnya maka semakin solid pula cabang-cabangnya dan dapat dipastikan akan menghasilkan daun yang rindang, bunga yang indah dan buah yang banyak, selain itu dengan adanya akar yang kokoh juga akan menjadikan suatu pohon tidak perlu khawatir apabila cabang-cabangnya di terpa angin yang kencang. Begitu pula halnya dengan hukum Islam, apabila akarnya kuat maka cabang-cabang fiqhnya tidak akan perlu khawatir apabila diterpa badai perkembangan zaman dan teknologi, karena cabang-cabangnya berdiri di atas akar yang kokoh, maka cabang-cabang fiqhnya juga akan menjadi kokoh, namun sebaliknya apabila akarnya lemah sebagus dan seindah apa pun cabang-cabang tadi pasti akan roboh apabila diterpa oleh badai, oleh karena itu amatlah benar apabila dalam kitab al Faraidh al Bahiyah disebutkan bahwa "sesungguhnya cabang-cabang masalah fiqh itu hanya dapat dikuasai dengan kaidah-kaidah fiqh, maka menghafalkan kaidah-kaidah itu amat besar fungsinya". ${ }^{9}$ Ungkapan di atas menggambarkan bahwa dengan memahami dan mendalami kaidah-

$9 \quad$ Asjmuni Abd. Rahman, Kaidah-kaidah Fiqh, Jakarta: Bulan Bintang, hlm. 17. 
kaidah fiqh, seorang mujtahid dapat mengetahui hukum terhadap masalah-masalah kontemporer yang muncul.

Terhadap kaidah-kaidah fiqh tersebut dapat dikatakan bahwa qowaid fiqhiyyah dapat menampung hukum-hukum syarak dari bermacam-macam persoalan yang berlainan antara satu dengan yang lain, sehingga Nadawi menyatakan bahwa fondasi fiqh yang bersifat universal tersebut mengandung hukum syarak yang bersifat umum, terhadap berbagai peristiwa yang termasuk dalam ruang lingkup qowaid fiqhiyyah tersebut. ${ }^{10}$ Oleh karena itu dapat disimpulkan bahwa qowaid fiqhiyyah dalam pembentukan hukum Islam mempunyai peranan sebagai berikut: ${ }^{11}$

1. Pendalaman terhadap kaidah-kaidah fiqh akan menjadikan seorang ahli hukum Islam, benar-benar dapat memahami ilmu fiqh dan mampu untuk menganalisis berbagai masalah kontemporer, yang kemudian dapat ditentukan hukum dari masalah tersebut.

2. Pemahaman terhadap qowaid fiqhiyyah dapat memudahkan proses penentuan hukum terhadap suatu masalah baru yang muncul, dengan mendalilkan pada adanya persamaan illat dan tidak bertentangan dengan ketentuan sebelumnya.

3. Pemahaman terhadap qowaid fiqhiyyah menjadikan hukum Islam selalu fleksibel, karena qowaid fiqhiyyah berfungsi sebagai filter yang menjamin supaya fiqh-fiqh kontemporer yang dibuat demi menyelesaikan persoalan kontemporer tersebut tidak bertentangan dengan ketentuan yang terdapat dalam nash (Al-Quran dan Sunnah).

Pentingnya pemahaman terhadap qowaid fiqhiyyah ini amat disadari betul oleh para Imam Empat Mazhab (Hanafi, Hambali, Maliki dan Syafií), hal ini dikarenakan ilmu tentang kaidah-kaidah fiqh ini merupakan salah satu cabang terpenting ilmu syariah, apabila dipelajari oleh seseorang maka akan menjadikan orang tersebut akan menjadi orang yang Faqih atau paham betul terhadap ilmu fiqh, bahkan menurut jumhur ulama rahasia-rahasia ilmu fiqh pada hakikatnya terletak pada kaidah-kaidah yang dikandungnya, di samping itu penguasaan terhadap ilmu qowaid fiqhiyyah akan memudahkan bagi seorang mujtahid untuk mengeluarkan fatwa, sehingga tidak dapat

10 Ali Ahmad al -Nadawi, al-Qawaid l Fiqhiyyah, Dar al Qalam, Damascus, hlm. 43.

11 Syarif Hidayatullah, Op.Cit., hlm. 37. 
dipungkiri pula bahwa penyebab utama dari keterbelakangan perkembangan hukum Islam disebabkan oleh kurangnya perhatian terhadap ilmu tentang qowaid fiqhiyyah. ${ }^{12}$

Pada dasarnya kaidah-kaidah fiqh yang dibentuk dan disepakati oleh para ulama ada banyak, namun dalam praktiknya jumhur ulama tetap berpedoman pada lima kaidah pokok utama atau yang lebih dikenal dengan istilah qawaid asasiyyah al khams, kelima kaidah pokok inilah yang kemudian melahirkan berbagai macam kaidah-kaidah cabang yang juga tetap merupakan bagian dari qowaid fiqhiyyah secara keseluruhan, dalam perkembangannya kelima kaidah pokok tersebut ditambahkan satu kaidah pokok oleh Ibnu Nujaim, sehingga dinamakan sebagai qawaid al kubra, namun demikian penggunaan lima kaidah pokok qawaid asasiyyah al khams, lebih popular di bandingkan dengan penggunaan lima kaidah pokok. Kelima kaidah pokok tersebut adalah suatu pedoman yang memastikan bahwa fiqh-fiqh yang di buat oleh manusia tidak bertentangan apa yang telah diatur oleh Allah SWT, nilai-nilai yang terkandung dalam kaidah-kaidah fiqh tersebut bersifat universal, yang dapat menyesuaikan dengan segala perkembangan zaman maupun permasalahan yang melekat padanya, dari kaidah-kaidah tersebut dapat di turunkan kembali menjadi kaidah-kaidah cabang yang bersifat lebih khusus yang berhubungan dengan persoalan yang hendak diselesaikan. Adapun kaidah-kaidah pokok dalam ilmu fiqh tersebut terdiri dari: 13

1. Kaidah pertama, "Segala urusan tergantung dari pada maksudnya".

2. Kaidah kedua, "Keyakinan tidak dapat dihapuskan atau dihilangkan dengan keraguan".

3. Kaidah ketiga, "Setiap kesulitan akan melahirkan suatu kemudahan”.

4. Kaidah keempat "Kemudharatan atau bahaya wajib untuk dihilangkan".

5. Kaidah Kelima "Adat istiadat dikokohkan".

6. Lima poin di atas adalah kaidah-kaidah pokok yang dinamakan dengan qawaid asasiyyah al khams, adapun kaidah tambahan yang sering disebut sebagai kaidah ke enam adalah "tidak ada pahala tanpa adanya niat", namun penggunaan kaidah ke enam ini jarang digunakan, oleh para mujtahid yang masih tetap berpedoman pada lima kaidah pokok di atas.

Adapun terhadap penjelasan dari masing-masing pengaplikasian dari kelima kaidah fiqh tersebut dapat di jabarkan di bawah ini:

12 Ibid.

13 Ibnu Nujaim, al Asyabah wa al Nazhaír, Dar al Fikr, Damascus, hlm. 115. 
1. Penjelasan terhadap kaidah pertama, "Segala urusan tergantung dari pada maksudnya", kaidah ini menekankan pentingnya niat dalam melakukan segala urusan, apabila niatnya baik maka hasilnya akan baik, namun sebaliknya apabila niatnya tidak baik maka hasilnya juga tidak akan baik. Dalam melakukan suatu ijtihad penting untuk dipahami bawa upaya tersebut harus di awali dengan niat yang baik, sehingga hasil ijtihad tersebut akan memiliki hasil yang baik, namun apabila ijtihad tersebut dilakukan tanpa adanya niat yang baik maka dapat dipastikan akan membawa dampak yang tidak baik, dengan kata lain suatu ijtihad dilakukan karena adanya kebutuhan akan solusi dari suatu persoalan, bukan karena pesanan, ataupun pesanan dari kepentingankepentingan segolongan manusia yang tidak membawa kebaikan bagi mayoritas manusia. Mengenai contoh penerapan kaidah ini adalah, misalkan dilakukan istinbath terhadap keabsahan transaksi keuangan menggunakan kartu elektronik, Al-Quran dan Sunnah tidak mengatur hal tersebut secara rinci, namun ada dasar-dasar muamalah yang dapat dijadikan illat dalam pembuatan aturan yang baru melalui upaya ijtihad, maka dalam hal ini upaya ijtihad tersebut adalah berupaya untuk mengakomodir kepentingan umat muslim terhadap transaksi keuangan menggunakan kartu dikarenakan perkembangan zaman yang memungkinkan adanya pembayaran dengan menggunakan kartu, ijtihad tersebut dilakukan semata-mata demi kemaslahatan umat muslim dalam bertransaksi, bukan karena adanya pesanan sponsor dari pihak bank ataupun pihak lain, oleh karena adanya niat untuk memudahkan umat muslim bertransaksi dan selama tidak ada kesamaan illat dalam Al-Quan dan Sunnah serta tidak bertentangan dengan dua sumber utama tersebut maka fiqh tentang transaksi elektronik tidak bertentangan dengan syariah Islam.

2. Kaidah kedua, "Keyakinan tidak dapat dihapuskan atau dihilangkan dengan keraguan", adapun penjabaran dari kaidah ini adalah penekanan pada suatu kondisi bahwa segala sesuatu yang telah ditetapkan sampai kapan pun tidak akan berubah, kaidah ini akan melahirkan kaidah cabang "al aslu makana la makana" yang dapat di artikan segala sesuatu yang sudah ada pada asalnya tidak akan berubah sampai kapan pun juga, makna keyakinan secara etimologi adalah sebuah ilmu yang tidak ada lagi keraguan di dalamnya, dalam 
pengertian lain dapat diartikan mengetahui secara pasti dan jelas akan suatu kebenaran. ${ }^{14}$

3. Kaidah ketiga, "Setiap kesulitan akan melahirkan suatu kemudahan”. Kaidah ini merupakan bukti nyata bahwa Islam tidak bertujuan untuk mempersulit umat manusia namun sebaliknya Islam sebagai rahmatan lil alamin bertujuan untuk membawa manusia kepada kemaslahatan, hukum yang ada bagi manusia tidak mempersulit dan tidak memberatkan namun selalu disesuaikan dengan kemampuan manusia, hal ini sebagaimana yang disebutkan dalam Q.S. Al Baqarah ayat $286,{ }^{15}$ kaidah ini dijadikan para fuqaha untuk memecahkan berbagai masalah dan menentukan hukumnya, bahwa dalam merumuskan hukum hendaknya tidak terlalu memberatkan, namun lebih bersifat untuk membawa kemaslahatan, oleh karena itu amatlah tepat apabila Asqolani menyatakan bahwa Islam adalah agama yang mudah yang ringan apabila dibandingkan dengan agama-agama samawi sebelumnya. ${ }^{16}$

4. Kaidah keempat "Kemudharatan atau bahaya wajib untuk dihilangkan". Pemahaman terhadap kaidah ini di awali dari pemaknaan yang kuat terhadap bahwa seseorang tidak boleh membahayakan orang lain, hal ini sebagaimana yang diatur dalam Q.S. Al A'Rof ayat 56 dan Q.S. Al Qashash ayat 77, kedua ayat tersebut memuat kata "wala tufsidu fil ardh", yang mempunyai makna dan janganlah kamu membuat kerusakan di muka bumi. Dari penjabaran tersebut dapat dipahami bahwa setiap umat manusia dilarang untuk membuat kerusakan di muka bumi dalam bentuk apa pun, termasuk juga dalam melakukan penafsiran makna yang terkandung dalam Al-Quran dan Sunnah, yang dimaksud dengan kerusakan di sini bukanlah kerusakan secara lahiriah saja atau kerusakan yang tampak secara fisik, namun lebih dari itu kerusakan tersebut juga meliputi kerusakan moral, pola pikir, akhlak dan mental. Atas dasar itulah maka kaidah pokok yang keempat ini muncul.

5. Kaidah Kelima "Adat istiadat di kokohkan". Yang dimaksud dengan adat di sini adalah kebiasaan atau urf yang dapat diterima oleh tabiat yang sehat dan dikerjakan berulang-ulang, dalam hal ini apabila suatu kebiasaan tersebut tidak

14 Syarif Hidayatullah, Op.Cit., hlm. 40.

15 Q.S. Al Baqarah tersebut mengatur bahwa "Allah tidak akan membebani seseorang melainkan sesuai dengan kesanggupannya....".

16 Ibnu Hajar Al Asqalani, Fath al Bary Syarh Shahih al Bukhari, Dar al Fikr, Beirut, hlm. 164. 
bertentangan dengan nash yang terkandung dalam Al-Quran dan Sunnah maka kebiasaan tersebut dapat dilakukan dan tidak perlu dipertentangkan lagi, dalam hal ini yang menjadi para meter dari adat istiadat ini adalah ketiadaan pertentangan dengan Al-Quran dan Sunnah, adanya pertentangan antara suatu adat istiadat dengan Al-Quran dan Sunnah secara otomatis akan menjadikan adat istiadat tersebut tidak dapat diterapkan dan tidak dapat dijadikan pedoman dalam melakukan penafsiran hukum. Penetapan adat istiadat sehingga menjadi hukum yang hidup di suatu masyarakat menekankan pada dua hal utama yaitu, pertama, tidak bertentangan dengan Al-Quran dan Sunnah dan yang kedua membawa kemaslahatan bagi umat manusia, oleh karenanya apabila suatu perbuatan tidak dilarang dalam Al-Quran dan Sunnah namun tidak membawa kemaslahatan sama sekali hendaknya tidaklah dikerjakan, karena hal tersebut hanya menimbulkan kemubaziran dan kesia-siaan saja, di satu sisi dapat juga mengarah kepada perbuatan syubhat yaitu perbuatan yang halal haramnya tidak jelas, yang apabila seseorang dihadapkan pada perkara syubhat maka hendaknya untuk di hindari, hal ini sebagaimana yang di sabdakan oleh Baginda Rasulullah SAW yang bersabda "barang siapa yang terjebak dalam perkara syubhat, maka sesungguhnya ia terjebak dalam perkara yang haram".

Demikianlah pembahasan qowaid fiqhiyyah, beserta contoh-contoh pengaplikasiannya, kelima kaidah dasar tersebut amat sangat dibutuhkan dalam proses pengaplikasian hukum Islam kontemporer, mengingat sifat universalitas dan generalitas Al-Quran dan Sunnah, membutuhkan alat sebagai pisau analisis demi menemukan makna yang hakiki dari dua sumber utama dalam hukum Islam tersebut, selain itu dengan ada qowaid fiqhiyyah maka secara tidak langsung hukum Islam dapat disesuaikan dengan perubahan dan perkembangan zaman melalui instrumen yang bernama fiqh, akan tetapi fleksibilitas hukum Islam tersebut hanya terhadap masalah-masalah duniawi saja, karena terhadap masalah-masalah yang menyangkut ketauhidan yang meliputi akidah dan ibadah tidak dapat dilakukan penafsiran lebih lanjut karena hal tersebut dapat menimbulkan bid'ah dan fitnah dalam memahami ajaran Islam yang sesungguhnya. 


\section{KESIMPULAN}

Pada dasarnya qowaid fiqhiyyah atau kaidah-kaidah fiqh berfungsi sebagai parameter pembentukan fiqh dalam hukum Islam kontemporer, supaya mempunyai kekuatan hukum dan tidak bertentangan dengan nash ataupun kemaslahatan, sehingga fiqh tersebut dapat diaplikasikan dalam kehidupan sehari-hari. Secara rinci qowaid fiqiyyah adalah kumpulan dari beberapa tuntunan yang berisi nilai-nilai yang harus dijadikan fondasi dasar pembentukan hukum Islam, oleh sebab itu qowaid fiqiyyah tersebut dapat dikelompokkan menjadi lima kaidah pokok/utama hukum Islam atau yang dikenal dengan istilah qowaid asassiyyah al khams. Kelima kaidah pokok tersebut mengatur tentang hal-hal pokok yang harus dipatuhi dalam upaya meng-isthinbath-kan suatu hukum yang dituangkan dalam suatu fiqh.

Secara praktis dapat dikatakan bahwa hukum Islam yang sebenarnya tidak lain adalah fiqh, yaitu daya upaya para fuqaha dalam menerapkan syariat Islam sesuai dengan kebutuhan masyarakat sekarang ini. Dimana dalam hal penyesuaian dengan perkembangan zaman hukum Islam mempunyai karakteristik yang khusus. Kekhususan dari karakteristik hukum Islam tersebut adalah takamul (sempurna), wasathiyah (harmonis), dan harakah (dinamis). Karena kefanatikan terhadap mazhab-mazhab terdahulu mengakibatkan terjadinya taqlid karena taqlid ini salah satu penyebab terhambatnya proses pembaruan hukum Islam agar sesuai dengan situasi dan kondisi sekarang. Karena tuntutan zaman di samping adanya kesadaran para cendekiawan Islam, maka muncullah penggerak pembaruan hukum Islam dengan berbagai pemikirannya. Dalam pembaruan hukum Islam ini perlu adanya peranan ijtihad dan kesadaran masyarakat dalam menerima pembaruan hukum Islam tersebut.

Upaya untuk mengetahui makna hakiki yang terkadang dalam Al-Quran dan Sunnah dapat dijembatani oleh qowaid fiqhiyyah, hal ini dikarenakan nilai-nilai yang terkadang dalam kaidah fiqh tersebut merupakan suatu garis besar yang harus diikuti ketika merumuskan fiqh, apabila ushul fiqh adalah metode untuk merumuskan fiqh, maka qowaid fiqhiyyah adalah pendekatan yang digunakan dalam metode tersebut, sehingga fiqh yang dihasilkan dapat dipastikan tidak bertentangan dengan dalil-dalil yang diatur dalam AlQuran dan Sunnah sekaligus dapat menjawab segala persoalan yang muncul di setiap aspek kehidupan masyarakat.

Qowaid fiqiyyah harus dijadikan pedoman dalam pembuatan suatu fiqh dalam hukum Islam, hal ini dikarenakan qowaid fiqiyyah tersebut tidak saja berusaha untuk 
memastikan bahwa fiqh tersebut tidak bertentangan dengan nash, sebagaimana yang terkandung di dalam Al-Quran dan Sunnah, namun lebih dari itu qowaid fiqiyyah tersebut juga menjadikan setiap fiqh mempunyai illat masing-masing yang membedakan antara fiqh yang satu dengan yang lain, yang mana illat tersebut muncul sebagai akibat dari adanya legal rationing yang melahirkan suatu hukum dalam hukum Islam. Hal ini amatlah penting mengingat setiap hukum pasti ada illatnya, karena tanpa adanya illat maka hukum tersebut tidaklah sempurna, bahkan dengan adanya illat inilah yang menjadikan hukumhukum yang terkandung dalam nash, menjadi fleksibel dan dinamis, sehingga dapat menjawab dan menyelesaikan segala persoalan di setiap zaman.

Pengaplikasian hukum Islam kontemporer amat tergantung dari pengaplikasian qowaid fiqhiyyah dalam ushul fiqh, sebagai kaidah baku yang sudah ditetapkan maka hal ini harus menjadi perhatian utama ketika melakukan pembahasan hukum Islam kontemporer, hal ini juga bertujuan untuk mematahkan omong kosong tentang Al-Quran dan Sunnah yang dikatakan telah ketinggalan zaman, karena sesungguhnya Al-Quran dan Sunnah di turunkan Allah SWT untuk menjawab segala persoalan d segala zaman dan sebagai wahyu dari Nabi terakhir Rasulullah SAW tentu tidak akan pernah ketinggalan zaman, hanya saja pemikiran manusia yang terkadang tidak mampu memahami secara sempurna makna Illahiah yang terkandung dalam Al-Quran dan Sunnah tersebut yang sering kali menimbulkan stigma negatif terhadap hal tersebut. Oleh karena itu qowaid fiqhiyyah ada sebagai penghubung antara kesempurnaan Illahiah dengan pemikiran fana manusia dalam memahami maksud dari sang pencipta alam semesta Allah SWT.

\section{Daftar Pustaka}

Abd. Rahman, Asjmuni, Kaidah-kaidah Fiqh, Bulan Bintang Jakarta.

Al Asqalani, Ibnu Hajar, Fath al Bary Syarh Shahih al Bukhari, Dar al Fikr, Beirut.

Ali Ahmad al -Nadawi, al-Qawaid al Fiqhiyyah, Dar al Qalam, Damascus.

Ash-Shiddiqy, Hasbi, Filsafat Hukum Islam, Pustaka Rizki Putra.

Hidayatullah, Syarif, Qawaid Fiqiyyah dan Penerapannya Dalam Transaksi Keuangan

Syariah Kontemporer (muámalat, maliyyah islamiyah, muásirah), Jakarta: Gramata Publishing, 2012.

Ibnu Nujaim, al Asyabah wa al Nazhaír, Dar al Fikr, Damascus.

Shomad, Abd, Hukum Islam: Penormaan Prinsip Syariah Dalam Hukum Indonesia, Cetakan Pertama, Jakarta: Kencana Prenada Media Group, 2010. 
Supriyatni, Renny, Pengantar Hukum Islam Dasar-Dasar Dan Aktualisasinya Dalam Hukum Positif, Bandung: Widya Padjadjaran, Maret 2011.

Thalib, Prawitra, Syariah: Konsep dan Hermeneutika, Cetakan Pertama, Surabaya: Lutfansyah Mediatama, 2013.

Warson, Ahmad, Kamus Al-Munawwir Arab-Indonesia, Pustaka Progressif, 1997. 